\title{
TYÖNTEKIJÖILTÄ ODOTETAAN YLEISIÄ PÄTEVYYKSIÄ, KYKYÄ SOPEUTUA JA JOUSTAVUUTTA
}

$\mathbf{K}$ aikissa pohjoismaissa on viime vuosina havahduttu huomaamaan, että kansainvälisen toimintaympäristön uudelleen jäsentyminen, työelämän jatkuva muuttuminen ja nuorten ikäluokkien pieneneminen edellyttävät tulevaisuudessa aikuisilta valmiuksia sopeutua jatkuvasti uudenlaisiin olosuhteisiin. Arvioitavana olevat kolme julkaisua lähestyvät kaikki aihetta hieman eri näkökulmasta. Kuvaan seuraavassa lyhyesti kunkin raportin keskeistä sisältöä ja esitän samalla joitakin kommentteja raportin annista uusiin haasteisiin vastaavan aikuiskoulutuksen kehittämisessä.

' 'Uusi aika - uusi työ - uusi koulutus"' on raportti aikuiskoulutuksen ja kansansivistystyön pohjoismaisen yhteistyön johtoryhmän (FOVU:n) ja pohjoismaisen työmarkkinatoimikunnan (NAUT:in) järjestämästä samannimisestä konferenssista 28.-30.8.1990. Konferenssin tavoitteena oli virittää keskustelua ja pohjoismaista kokemusten vaihtoa siitä, miten yleissivistävän ja ammatillisen aikuiskoulutuksen yhdistämisellä voitaisiin parantaa koulutustasoa ja viihtyvyyttä työelämässä sekä työttömien työnsaantimahdollisuuksia. Konferenssin järjestämistä perusteltiin sillä, että työvoimalle 1990-luvulla asetettavien pätevyysvaatimusten katsottiin edellyttävän sektoreiden välisen yhteistyön tiivistämistä. Konferenssissa oli osanottajia sekä työmarkkinasektorilta että aikuiskoulutuksen alalta. Raportissa toivotaan, että konferenssin seurauksena syntyisi uusia yleissivistävän ja ammatillisen aikuiskoulutuksen yhteistyöprojekteja.

Vaikka yleissivistävän ja ammatillisen koulutuksen välisten yhteyksien luominen oli jo konferenssin lähtökohta, käytettiin siinä kuitenkin aikaa myös yhteistyön perustelujen tarkempaan pohtimiseen.
Uusi aika - uusi työ - uusi kouhutus

Pohjoismaiden ministerineuvosto

Kansansivistys ja aikuiskoulutus

Nord 1991:11

Qualifications in the year 2001

Danish Research and Development

Centre for Adult Education

June 1991

Kompetensutveckling - en nationell

strategi

Slutbetänkande från kompetensutred-

ningen

SOU $1992: 7$

Ensinnäkin katsottiin työvoimalle asetettavien vaatimusten lisäävän laaja-alaisen yleissivistävän ja ammatillisen koulutuksen saaneen työvoiman kysyntää. "Yhteiskunnan kehitys, mukaan luettuna tekniikan kehitys, edellyttää yrityksiltä jatkuvaa sopeutumiskykyä. Niinpä työntekijöiltä vaaditaan avoimuutta ja joustavuutta, jotka ovat edellytys yksilölliselle, elinikäiselle sopeutumiskyvylle." Vaatimus elinikäisestä sopeutumisprosessista katsottiin voitavan täyttää ainoastaan silloin, kun ammatilliseen pätevöitymiseen sisällytetään myös yleissivistävää koulutusta.

Toiseksi katsottiin, että laaja-alaisesti pätevöittävä aikuiskoulutus voi olla edellytys sille, että yksilö pystyy hankkimaan toimeentulonsa, ymmärtämään uusia elämäntilanteita sekä analysoimaan arkipäivään ja yhteiskuntaelämään kuuluvia päätöksiä ja osallistumaan päätöksentekoon. 


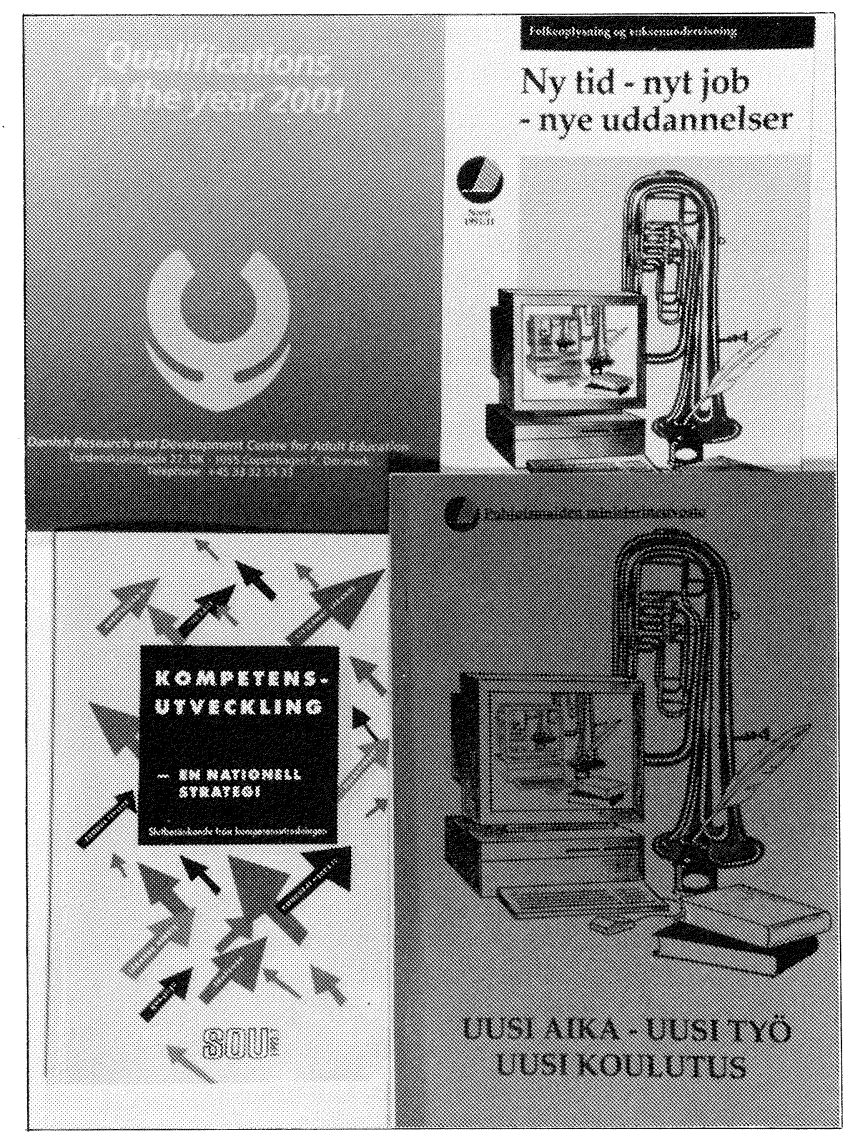

Lisäksi katsottiin, että uudet yhteistyömuodot oppilaitosten välille laajentavat niiden kaikkien kokonaisnäkemystä ja että eri koulutusorganisaatioiden erityisvahvuudet lisäävät mahdollisuuksia ottaa huomioon kurssilaisten elämänkokemukset ja soveltaa opittua työelämässä ja arjessa.

K onferenssissa esiteltiin myös käytännön esiI merkkejä yleissivistävän ja ammatillisen koulutuksen yhteistyöstä eri maista. Pääosin esimerkeissä oli kysymys tavanomaisen koulutustarjonnan organisoimisesta uudella tavalla niin, että osia alkuperäiseen ohjelmaan sisältyvästä koulutuksesta siirrettiin järjestettäväksi muihin oppilaitoksiin. Osittain oli kysymys myös uudenlaisista koulutusohjelmista, joissa koulutukseen osallistuvan ryhmän lähtökohdista etsittiin uusia koulutussisältöjä ja uudenlaisia tavanomaisen koulutustarjonnan yhdistelmiä.
Yhteistyöstä oli saatu sekä hyviä että huonoja kokemuksia. Hyvät kokemukset koskivat lähinnä uudenlaisen koulutustarjonnan aikaansaamista. Keskeisiksi ongelmiksi oli havaittu yhteistyötä vaikeuttavat erot eri aikuiskoulutusmuotojen hallinnossa ja organisaatiossa sekä erilaiset käsitykset siitä, minkälaiset tiedot ja taidot ovat olennaisia työelämässä. Erityisesti katsottiin, että yleissivistävän aikuiskoulutuksen asemaa ja laajuutta ei ollut ymmärretty tarpeeksi.

Raportti on hajanainen kuten konferenssiraporteilla usein on tapana olla ja siinä esitetyt tulevaisuuteen suuntautuvat johtopäätökset jäävät varsin vähäisiksi. Yhdessä suhteessa raportti on kuitenkin, ehkä tahattomasti, hyvin hyödyllinen. Se kuvaa oivallisesti tilannetta, johon joudutaan, kun ajassa liikkuvaa yleistä näkemystä koulutustarpeesta lähdetään muuntamaan koulutukseksi ilman näkemyksen pitemmälle menevää analysointia.

A ikuiskoulutuksen eri muotojen edustajat ovat konferenssissa ja raportissa kuvatuissa käytännön esimerkeissä selvästikin olleet yhtä mieltä siitä, että aikuiset tarvitsevat uudenlaista laajaa perusosaamista, jonka varassa kehittyminen ja muuttuminen on mahdollista. Yhteisymmärryksen saavuttaminen siitä, mitä tämä perusosaaminen konkreettisemmin sanottuna on ja millaisilla koulutusohjelmilla sen kehittymistä voidaan tukea, onkin jo sitten osoittautunut vaikeaksi. Sen vuoksi on jouduttu vain toteamaan yleisesti, että perusosaaminen rakentuu sekä ammatillisesta että yleissivistävästä koulutuksesta. Koulutusorganisaatiot ovat sitten tarjonneet perusosaamisen rakennuspuiksi lähinnä niiden jo perinteisesti tarjoamaa koulutusta ja vaatineet muita osapuolia hyväksymään niiden koulutustarjonnan ja erityispätevyyden. Käytännön yhteistyö on sitten muodostunut perinteisten ammatillisen ja yleissivistävän koulutuksen osien liittämisestä uudenlaisiksi peräkkäisiksi koulutuskokonaisuuksiksi.

Kun eri tehtäviä hoitavien koulutusorganisaatioiden toimintaa ohjaavat säännökset ovat erilaisia, on yhteistyö aiheuttanut väistämättä myös hallinnollisia ja rahoituksellisia yhteensovittamisongelmia. Säännösten yhtenäistäminen puolestaan ei ole juurikaan edennyt ilmeisesti siksi, että hallinnolla ei ole ollut riiittävää käsitystä muutosten perimmäisenä tavoitteena olevasta perusosaamisesta. 
"'Qualifications in the year 2001" on Tanskan aikuiskoulutuksen tutkimus- ja kehittämiskeskuksen julkaisema raportti, joka käsittelee aikuisten tulevaisuudessa tarvitsemia pätevyyksiä ja niiden hankkimismahdollisuuksia. Esipuheen mukaan julkaisun toivotaan kiinnostavan ja innostavan niitä, jotka tekevät aikuiskoulutuksen tulevaisuutta koskevia päätöksiä kansallisella ja eurooppalaisella tasolla.

$\mathbf{R}^{2}$ aportin lähtökohtana on, että ammattitaitovaatimusten kasvu ja nuorten määrän väheneminen edellyttävät välttämättä investoimista työmarkkinoilla oleviin aikuisiin. Työmarkkinoiden keskeisenä piirteenä nähdään jatkuva muutos, jonka kanssa ihmisten on opittava elämään. Koulutusjärjestelmän edellytetään muuttuvan radikaalisti. "Koulutuksen tulee auttaa meitä olemaan joustavia, yhteistyökykyisiä, luovia ja itsenäisiä. Meidän täytyy oppia näkemään muutokset kannustavina eikä pelätä niitä. Koulutusjärjestelmän tulee opettaa meitä hapuilemaan pimeässä, etsimään uusia mahdollisuuksia ja tuntemaan itsemme."

Julistuksenomaisen johdannon jälkeen raportissa esitetään pätevyystyypittely, joka jakaa pätevyydet henkilökohtaisiin ja ammatillisiin, laaja- ja kapeaalaisiin sekä muodollisiin ja ei-muodollisiin. Tyypittelyssä ei sinänsä ole mitään erityistä. Mielenkiintoista on sen käyttö havainnollistamaan aikuiskoulutuksen suuntaamisesta käytävän keskustelun sisältöä.

$\mathbf{H}$ enkilökohtaisilla pätevyyksillä raportissa tarkoitetaan koulutusjärjestelmässä hankittuja perustietoja ja -taitoja, sosiaalisia ja fyysisiä taitoja sekä henkilökohtaisia perusominaisuuksia kuten riippumattomuutta, itseluottamusta ja joustavuutta. Henkilökohtaiset pätevyydet voivat olla kapea-alaisia, spesifistä tiedosta muodostuvia tai laaja-alaisia, yleisiä ominaisuuksia ja asenteita edellyttäviä. Ammatilliset pätevyydet liittyvät tiettyyn työhön. Nekin voivat olla kapea-alaisia, spesifejä teknisiä tietoja ja taitoja edellyttäviä tai laaja-alaisia, laajaa näkemystä edellyttäviä.

Muodolliset pätevyydet hankitaan koulutusprosesseissa, jotka tarjoavat henkilölle halutun ammatillisen tiedon ja taidon sekä niihin liittyvän todistuksen. Osanottajien katsotaan tällöin olevan passiivisia oppijoita. Ei-muodolliset pätevyydet ovat tulosta arkioppimisesta tai kokemuksesta, jossa päätavoitteena on henkilökohtainen kehittyminen. Silloin kun kysymyksessä on koulutus, siinä on otettu huomioon opiskelijoiden yksilölliset vaatimukset. Osanottajien katsotaan tällöin olevan aktiivisia oppijoita.

Yläkäsitteenä käytetään elämänpätevyyttä, jolla tarkoitetaan kaikkia elämän eri vaiheissa hankittuja tietoja, taitoja, kokemuksia ja mielipiteitä. Elämänpätevyyden katsotaan syntyvän toisaalta elämästä oppimisesta eli henkilökohtaisesta normien, arvojen ja kokemuksen hankkimisesta ja toisaalta kontrolloidusta valmiuksien hankkimisesta opiskelemalla. Tyypittelyä käytetään kuvaamaan eräiden lyhyen ammatillisen $h$ ulutuksen saaneille koulutusta järjestävien organisaatioiden toiminnan painopistettä sekä Tanskan työnantajien keskusliiton esittämää luetteloa siitä, mihin pätevyyksiin työnantajat kiinnittävät huomionsa tulevaisuudessa.

Oppiainejakoista yleissivistävää aikuiskoulutusta tarjoavissa aikuiskoulutuskeskuksissa painopiste asettuu raportin mukaan kapeisiin, muodollisiin henkilökohtaisiin pätevyyksiin. Päiväkansanopistoissa, joissa koulutus perustuu laajempiin teemoihin ja joissa innoittavaa opiskeluprosessia pidetään yhtenä keskeisenä tavoitteena, painopiste asettuu laajoihin, ei-muodollisiin henkilökohtaisiin pätevyyksiin. Tuotantokouluissa, joissa tavoitteena on todellisia tuotanto-olosuhteita vastaavissa oloissa auttaa työttömiä tai kouluun väsyneitä nuoria aikuisia palaamaan tavanomaiseen koulutusjärjestelmään tai työmarkkinoille, painopiste asettuu laajoihin, ei-muodollisiin henkilökohtaisiin ja ammatillisiin pätevyyksiin. Työmarkkinakoulutuksessa painopiste asettuu kapeisiin, muodollisiin ammatillisiin pätevyyksiin. Raportin tämä osuus on puhtaasti kuvaileva. Painopisteiden asettumista ei kommentoida mitenkään.

$\mathrm{T}$ anskan työnantajien keskusliitto oli vastannut tutkimus ja kehittämiskeskuksen kysymykseen siitä, mihin pätevyyksiin työnantajat kiinnittävät huomiota tulevaisuudessa, seuraavalla luettelolla: haluun tehdä lujasti työtä, luotettavuuteen, kykyyn pysyä työtahdissa mukana, ammatillisiin taitoihin, opiskelukykyyn ja kykyyn olla realistinen harkitessaan omia mahdollisuuksiaan kussakin työllisyystilanteessa. Lisäksi työnantajat pitivät tärkeänä laajempaa ammatillista ja alueellista liikkuvuutta.

Luettelo sijoitetaan raportissa tyypittelyyn ja havaitaan, että painopiste asettuu laajoihin, ei- 
muodollisiin henkilökohtaisiin pätevyyksiin. ',Pääpaino on ensisijaisesti henkilökohtaisissa ja moraalisissa piirteissä. Spesifit ammatilliset tiedot ja taidot ovat välttämättömiä, mutta eivät yksinään riittäviä, jotta yksilö voi pärjätä työmarkkinoilla." Tästä johdetaan joukko perustavaa laatua olevia kysymyksiä. Onko aikuiskoulutusjärjestelmä valmis kohtaamaan uudet haasteet? Millaista koulutuksen tulisi olla sisällöltään ja miten se pitäisi organisoida? Miten koko työvoiman kehittäminen voidaan taata?

Työnantajien näkemysten todetaan sitten olevan yhteneväisiä lähes kaikkien asiasta kiinnostuneiden tahojen näkemysten kanssa: kaikki aikuiskoulutuksen kanssa tekemisissä olevat ovat jo pitkään vaatineet yleisiä pätevyyksiä, kykyä sopeutua ja joustavuutta.

Sen jälkeen raportti huipentuu uuteen kysymyssarjaan. Miksi sitten kapeille ja spesifeille sisällöille annetaan kuitenkin etusija, kun kursseja suunnitellaan? Miksi laajat henkilökohtaiset ja moraaliset ominaisuudet asetetaan etualalle kun pätevyysvaatimuksista keskustellaan, mutta oppiaineet ja taidot, jotka voidaan mitata ja arvioida, sisällytetään koulutussuunnitteluun?

Vastaukset annetaan myös kysymyksen muodossa. Siksikö, että suuresti kysyttyjen laajojen pätevyyksien katsotaan kuuluvan vasta kaukaiseen tulevaisuuteen? Siksikö, että laajat pätevyydet ovat hankalia käsitellä ja vaikeita sijoittaa spesifiin kurssiin? Siksikö, että henkilökohtaiset ominaisuudet ovat perittyjä, niin että meidän ei tarvitse kulkea koulutuksen läpi niiden saavuttamiseksi? Ja jos joku jää ulos, onko se hänen omien puutteidensa syy? Katsotaanko kerettiläiseksi kursseja suunniteltaessa myöntää, että tänä muutosten aikana aikuiset tarvitsevat elämästä oppimista yhtä paljon kuin paperipätevyyksiä? Vai olemmeko me ainoat, jotka ovat huomanneet ristiriidan sanojen ja tekojen välillä?

$\mathbf{R}$ aportti päättyy lainaukseen Hans Christian Andersenin sadusta, jossa sankari selviytyy vaaroista ja saavuttaa tavoitteensa mielikuvituksensa, rohkeutensa ja itseluottamuksensa avulla.

Tässä raportissa on päästy selvästi pitemmälle kuin edellisessä. Tekijät osoittavat havainnollisella tavalla näkemyksensä siitä, minkä tyyppistä sellaisen koulutuksen tulisi olla, joka todella auttaa ih- misiä kehittymään entistä joustavammiksi ja muuntautumiskykyisemmiksi.

Oivallisen jännitteen raporttiin tuo se, että tällaisen koulutuksen osoitetaan toisaalta olevan työnantajien tavoitteena ja toisaalta jo toteutuvan päiväkansanopistojen ja tuotantokoulujen tavoitteilla toimivassa koulutuksessa. Raportin tekijät ovat ilmeisesti kiertotietä halunneet sanoa, että tulevaisuuden työntekijöiden koulutuksen ydin onkin siis löydettävissä työmarkkinoilta syrjäytymässä oleville suunnitellun koulutuksen sisällöistä ja menetelmistä. Olisiko Suomessakin ammatillisen koulutuksen kehittämisessä otettava oppia ohjaavan koulutuksen piirissä kehitellyistä ratkaisuista?

\begin{abstract}
"'Kompetensutveckling - en nationell strategi' on ruotsalainen komiteanmietintö, joka käsittelee työelämässä tapahtuvaa työntekijöiden pätevyyden kehittämistä. Sen lähtökohtana on, että Ruotsin elinkeinoelämä on 1990-luvulla vaikeiden rakennemuutosten edessä. Kansainvälistyminen, kiristynyt kilpailu, tietotekniikan kehitys ja tuotteiden yksilöllistyminen aiheuttavat muutospaineen, joka on voimakkaampi kuin ehkä koskaan aikaisemmin. Väestön ikärakenteen muutos ja tuottavuuden alhainen kasvunopeus vaikeuttavat lisäksi välttämätöntä sopeutumista uusiin ehtoihin. Komitean johtopäätös on, että koko työmarkkinoilla tarvitaan erittäin voimakkaita panostuksia tietoon ja pätevyyteen, mikäli halutaan säilyttää Ruotsin hyvinvointi.
\end{abstract}

$T$ oimenpide-ehdotustensa perustaksi komitea tekee mielenkiintoisella tavalla eron yleisen koulutusjärjestelmän ja työelämässä tapahtuvan pätevyyden kehittämisen välille. Yleisen koulutusjärjestelmän yhteiskuntataloudellinen tavoite on muuttaa koulutuksen avulla työvoiman kvalifikaatioita ja sitä kautta pitkällä tähtäimellä myös työn sisältöä ja työorganisaatiota. Työelämässä tapahtuvassa pätevyyden kehittämisessä koulutustarve puolestaan syntyy vastauksena muutoksiin työorganisaatiossa ja työn sisällössä. Koulutus on siis tässä perspektiivissä seuraus muutosprosessista, joka alkaa siitä, että työorganisaatio ja työtehtävät muuttuvat. Jos tätä koulutusnäkemystä, suoraa sopeutumista tuotannon vaatimuksiin, sovellettaisiin yhteiskunnan tasolla, se aiheuttaisi vakavia häiriöitä pitemmällä tähtäimellä. 
Yleinen koulutusjärjestelmä on komitean näkemyksen mukaan investointi ihmisiin. Yhteiskunnan tasolla koulutus on ratkaiseva kehitettäessä pitkällä tähtäimellä sekä korkeaa laatua että kilpailukykyä. Koulutusjärjestelmän pitkäjänteisiin tavoitteisiin, so. korkeisiin yleisiin kvalifikaatioihin suunnattu koulutus johtaa siihen, että kyseessä olevan maan työelämästä voi muodostua pitkälle kehittynyt. Koulutusjärjestelmän sopeuttaminen työmarkkinoiden olemassa oleviin tai nähtävissä oleviin tarpeisiin johtaisi alaspäin suuntautuneeseen sopeutumisspiraaliin.

T yöpaikkojen perspektiivistä komitea näkee tilanteen toisenlaisena. Pätevyyden kehittäminen on osa ylläpito- ja uudistumisprosessia. Sen täytyy olla käynnissä jatkuvasti ja muodostaa integroitu osa toimintaa. Koulutustoiminnat eivät ole muutoksen käynnistin. Ne johdetaan muutoksista työorganisaatiossa ja työtehtävissä. Komitea katsoo, että paikallisiin työmarkkinoihin ja paikalliseen työelämään suunnattuja yhteiskunnan panostuksia leimaa liiallisesti yleisen koulutusjärjestelmän katsantokanta. Komitea kuitenkin korostaa, että työntekijät tarvitsevat sekä yleisen koulutusjärjestelmän antamia yleisemmin käyttökelpoisia valmiuksia että työpaikoilla tapahtuvaa pätevyyden kehittämistä.

Komitea toteaa edelleen, että voimakkaatkaan panostukset työelämässä tapahtuvaan pätevyyden kehittämiseen eivät tuota tulosta, ellei työorganisaatiota samalla muuteta. Tässä yhteydessä komitea viittaa tekemäänsä kansainväliseen tutkimuskatsaukseen, jonka mukaan kilpailussa menestyneiden maiden ja yritysten ratkaiseva kilpailuetu on ollut lavennettu ja integroitu työorganisaatio, johon on yhdistynyt panostaminen kaikkien työntekijöiden pätevyyden kehittymiseen. Komitea katsoo, että tavoitteena on oltava "oppiva organisaatio", jossa hierarkioita ja erikoistumista vähennetään, työn sisältöä laajennetaan ja vastuuta ja valtuuksia delegoidaan.

$\mathbf{K}^{\mathrm{o}}$ omitean toimenpide-ehdotukset muodostuvat viidestä osa-alueesta. Yrityksille ja julkisyhteisöille, jotka itse panostavat pätevyyden kehittämiseen ja täyttävät tietyt suunnitelmallisuuden ehdot, ehdotetaan taloudellista tukea. Työmarkkina-, elinkeino-, alue-, sosiaali- ja koulutuspolitiikan tavoitteita ehdotetaan laajennettavaksi niin, että ne käsittävät myös pätevyyden kehittämisen. Samalla ehdotetaan, että näiden politii- kan alueiden voimavarat kootaan yhteen alueellisella ja paikallisella tasolla. Tässä yhteydessä ehdotetaan myös erilaisten alueellisten ja alakohtaisten toimintojen koordinointia, kehittämistä ja taloudellista tukemista. Naisten pätevyyden kehittämiseksi ehdotetaan erityistoimia. Yksilöllistä pätevyyden kehittämistä ehdotetaan tuettavaksi näyttökoejärjestelmällä, nykyistä lyhyempien koulutuspakettien ja niihin liittyvän taloudellisen tuen kehittämisellä sekä siirtolaisiin ja pakolaisiin kohdistuvilla erityistoimilla. Lopuksi ehdotetaan laajaa tutkimus- ja kehittämistoimintaa yhteistyössä korkeakoulujen kanssa.

Komiteamietintö käsittelee aikuisilta tulevaisuudessa edellytettäviä valmiuksia edellä esitellyistä raporteista poikkeavalla tavalla. Koska kysymyksessä on komiteamietintö, käsittelyn taso on myös huomattavasti edellisiä perusteellisempi. Mielenkiintoisinta mietinnössä on mielestäni yleisen koulutusjärjestelmän ja työelämässä tapahtuvan pätevyyden kehittämisen lähtökohtien ja tavoitteiden erittely. Komitean johtopäätös on, että yhteiskunnan on syytä tukea kumpaakin aikuisten valmiuksien kehittämistapaa mutta selvästi muistaen, kummasta on kulloinkin kysymys. Mielenkiintoinen on myös komitean näkemys siitä, että työelämässä tapahtuva pätevyyden kehittäminen ei onnistu perinteisessä hierarkkisessa ja pitkälle eriytyneessä työorganisaatiossa.

S uomessa tätä komiteamietintöä vastaavaa käytännön toimenpideohjelman tasolle asti ulottuvaa työtä ei ole vielä tehty, vaikka työelämän pedagogisoiminen tai siirtyminen koulutusyhteiskunnasta oppimisen yhteiskuntaan ajatuksena onkin ollut jo pitkään esillä. Kannattaisiko tässäkin asiassa seurata ruotsalaisten esimerkkiä? 